\title{
К ФИТОХИМИЧЕСКИМ ИССЛЕДОВАНИЯМ CISTANCHE SALSA (OROBANCHACEAE)
}

\author{
() Ж.Ж. Каржаубекова ${ }^{I^{*}}$, Н.Г. Гемеджиева ${ }^{1}$, Ж.С. Набиева ${ }^{2}$ \\ ${ }^{1}$ РГП «Институт ботаники и фритоинтродукции» КН МОН РК, \\ ул. Тимирязева, 36д, Алматы, 050040 (Республика Казахстан), \\ e-mail: zhanna1322@mail.ru \\ ${ }^{2}$ Алматинский технологический университет, ул. Толе би, 100, Алматы, \\ 050012 (Республика Казахстан)
}

Определено содержание некоторых групп БАВ: флавоноидов, кумаринов, алкалоидов, углеводов, полисахаридов в столонах цистанхе солончаковой, произрастающей в саксаульниках на территории Балхашского и Панфиловского административных районов Алматинской области, а также в песках Мойынкум на территории Жамбылской области.

Впервые проведен анализ на содержание жирных и аминокислот, а также макро- и микроэлементного состава образцов цистанхе, собранных в Панфиловском районе, в результате чего обнаружено 14 амино- и восемь жирных кислот. Из выявленных аминокислот преобладают аргинин, пролин и серин. Анализ жирных кислот преимущественно представлен линолевой, пальмитиновой кислотами $(>0,1 \%)$. Макро- и микроэлементный состав выявил наличие 10 элементов: K, $\mathrm{Na}, \mathrm{Mg}, \mathrm{Ca}, \mathrm{Al}, \mathrm{Fe}, \mathrm{Mn}, \mathrm{Zn}, \mathrm{Cu}$ и Ni. Причем наибольшее содержание отмечено для К, $\mathrm{Na}$ и $\mathrm{Ca}(0,8 \%)$, среди микроэлементов больше накапливается Zn.

Проведен сравнительный анализ водно-спиртовых извлечений, который показал, что качественный состав веществ фенольного характера в исследуемых образцах практически одинаков. Методом двумерной бумажной хроматографии с использованием различных систем растворителей обнаружено пять веществ фенольной природы. Содержание флавоноидов определили в пределе $2,8-4,8 \%$.

Установлены высокие показатели содержания углеводов (до 32\%) и полисахаридов (>13\%). элементы.

Ключевые слова: Cistanche salsa, фитохимический анализ, амино- и жирнокислотный состав, макро- и микро-

\section{Введение}

Фитохимическое исследование растений-паразитов, которые приспосабливаются к «растениямхозяевам», представляет большой интерес. Первые шаги в изучении паразитирующих растений проявились в работах И.Г. Бейлина [1].

Виды рода цистанхе Cistanche Hoffmgg. et Link относятся к семейству Заразиховых Orobanchaceae Vent., которое насчитывает более 25 видов, произрастающих в странах Средиземноморья, Западной и Средней Азии. Во флоре Казахстана род цистанхе представлен тремя видами: цистанхе сомнительная (C. ambigua (Bunge) G. Beck, ц. желтая C. flava (C. А. Mеу.) Korsh. и ц. солончаковая (C. salsa (C. А. Меу.) G. Beck) [2, 3]. По данным C.A. Абдулиной [4], род Cistanche насчитывает пять видов, среди которых рассмотрены вышеперечисленные виды и включены ц. монгольская C. mongolica G. Beck и ц. рассеченная (C. fissa (C. A. Mey.) G. Beck.

Каржаубекова Жанат Жумабековна - кандидат химических наук, старший научный сотрудник лаборатории растительных ресурсов, e-mail: zhanna1322@mail.ru

Гемеджиева Надежда Геннадьевна - доктор биологических наук, заведующая лабораторией растительных ресурсов, e-mail: zhanna1322@mail.ru Набиева Жанар Серикболовна - $\mathrm{PhD}$, заведующий аккредитованной испытательной лаборатории «Пищевая безопасность», e-mail: zhanna1322@mail.ru
Данная работа явилась продолжением фитохимических исследований паразитирующего вида цистанхе солончаковой Cistanche salsa (C. А. Mey.) G. Beck из сем. Заразиховых Orobanchaceae Vent., которые проводятся в последние годы в лаборатории растительных ресурсов Института ботаники и фитоинтродукции [5]. Современная оценка степени изученности, особенностей распространения, фитоценоти-

\footnotetext{
* Автор, с которым следует вести переписку.
} 
ческой приуроченности и сырьевой базы данного вида в Южном Прибалхашье на территории Алматинской области рассмотрены в работах Н.Г. Гемеджиевой и др. [6-8].

Цистанхе солончаковая Cistanche salsa - многолетнее травянистое растение, паразитирует на видах p. Anabasis L., p. Kalidium Moqq., p. Salsola L., редко p. Calligonum L. Встречается на солонцах и солончаках, в пустынных степях почти всего равнинного, мелкосопочного и подгорного Казахстана [3].

Фитохимическая изученность растений рода цистанхе показала высокое содержание полисахаридов, фенилэтаноидов и стеринов $[9,10]$. Имеются данные по содержанию иридоидов, лигнанов, фитостеринов, углеводов, моно- и сесквитерпеноидов, органических кислот, фенольных гликозидов, а также флавоноидов и алкалоидов для C. salsa [11-13].

Суммарные экстракты C. tubulosa, C. deserticola, C. salsa обладают гипохолестеронолитическим, эстрогенным, иммуномодулирующим, противоопухолевым, тонизирующим действием [14-16]. Определена антибактериальная и антиоксидантная активность экстракта C. salsa, содержащего полифенольные соединения [17].

Несмотря на проводимые фитохимические исследования некоторых представителей р. Cistanche, казахстанский вид цистанхе солончаковой в этом отношении слабо изучен, и целью данной работы явилось определение содержания некоторых групп биологически активных веществ (БАВ), амино- и жирных кислот, а также макро- и микроэлементного состава столонов C. salsa.

\section{Экспериментальная часть}

Исследуемые образцы цистанхе солончаковой собраны в фазу цветения в конце апреля 2013, 2014, 2015 гг. в саксаульниках на территории Балхашского (в окрестностях поселка Акжар) и Панфиловского (в окрестностях поселка Айдарлы) районов Алматинской области и в песках Мойынкум Сарысуйского района Жамбылской области. При заготовке столонов растения выкапывали, отряхивали от земли и промывали в проточной холодной воде, обсушивали и нарезали тонкими слайсами. Сушку осуществляли воздушно-теневым способом, разложив нарезанное сырье одним слоем, периодически перемешивая. Полученное сухое сырье измельчали и просеивали.

Определению количественного содержания некоторых БАВ предшествовал качественный анализ сырья, показавший их наличие в анализируемых образцах [5].

Количественный анализ исследуемых БАВ проводили по общепринятым методикам [18]. Содержание флавоноидов определяли спектрофотометрическим методом, оптическую плотность раствора измеряли при длине волны 430 нм.

Содержание кумаринов определяли спектрофотометрическим методом. Оптическую плотность раствора измеряли при длине волны 272 нм в кювете с толщиной слоя 10 мм, используя в качестве раствора сравнения спирт этиловый 95\%. Содержание производных кумарина в абсолютно сухом сырье вычисляли по формуле:

$$
X=\frac{D * 25 * 100 * 100}{734 * 20 * m *(100-w)}
$$

где D - оптическая плотность испытуемого раствора при длине волны 272 нм; 734 - удельный показатель поглощения стандартного образца кумарина при длине волны 272 нм; 20, 25 - объем мерных колб, использованных для разведения хлороформных извлечений анализируемых образцов, мл; $\mathrm{m}$ - масса навески исследуемого растительного сырья, г; W - потеря массы при высушивании исследуемого растительного сырья, \%.

Количественное содержание алкалоидов определяли титриметрическим способом. Для выделения алкалоидов из столонов цистанхе проводили экстракцию смесью хлороформа и гидроксида аммония, встряхивали на вибрационном аппарате в течение 2 ч. Хлороформное извлечение отфильтровывали и отгоняли досуха. К полученному экстракту прибавляли минимальный объем 0,1 М раствора едкого натра, затем добавляли 10 мл 0,1 М раствора хлороводородной кислоты, встряхивали в течение 10 мин и отфильтровывали через тройной бумажный фильтр. Избыток кислоты в фильтрате определяли раствором гидроксида натрия 0,01 М в присутствии индикатора метилового красного до появления желтого окрашивания. 
Содержание сапонинов определяли спектрофотометрическим методом, оптическую плотность измеряли при длине волны 258 нм в кювете с толщиной слоя 1 см. Извлечение сапонинов проводили ацетоном в присутствии 3\% азотной кислоты в течение 1 ч. Экстракцию проводили трижды, извлечения объединяли и отфильтровывали.

Определение содержания углеводов проводили фотометрически фенолсернокислотным методом. Оптическую плотность проб измеряли на спектрофотометре при длине волны 490 нм. Содержание углеводов определяли по калибровочному графику глюкозы, при концентрациях от $1 \times 10^{-5}$ до $6 \times 10^{-5}$ г/мл.

Общее содержание полисахаридов (ПС) определяли гравиметрическим методом. Экстракцию проводили водой, ПС осаждали трехкратным объемом 96\% спирта. Полученный раствор подогревали на водяной бане при $60{ }^{\circ} \mathrm{C}$ в течение 5 мин, затем центрифугировали с частотой 5000 об./мин. в течение 30 мин. Образовавшийся осадок и надосадочную жидкость отфильтровывали, высушивали при $100-105^{\circ} \mathrm{C}$, взвешивали и вычисляли общее содержание ПС.

Количественное определение амино- и жирных кислот, макро- и микроэлементов проводили в аккредитованной испытательной лаборатории «Пищевая безопасность» Алматинского технологического университета г. Алматы.

Определение аминокислот проводили на системе капиллярного электрофореза «Капель 105 М» (РФ) после предварительного гидролиза растительного сырья соляной кислотой $(1: 1)$ при $105{ }^{\circ} \mathrm{C}$ в течение 14 16 ч [19]. Кислотный гидролизат упаривали до минимального объема на роторном испарителе и далее переводили в фенилизотиокарбомильные производные. После разделяли и количественно определяли методом капиллярного электрофореза. Детектирование проводили в УФ области при 254 нм.

Содержание жирных кислот определяли на газо-жидкостном хроматографе «Кристал-4000» (РФ) после предварительного извлечения липидов из исследуемого материала гексаном на аппарате Соксклета в течение 5 ч. Экстракт упаривали досуха в круглодонной колбе на роторном испарителе при температуре $30-40{ }^{\circ} \mathrm{C}$.

Этилирование проводили в смеси гексан (97\% и более), 25\% этилат натрия в абсолютном этиловом спирте и уксусной кислоты. После интенсивного перемешивания в течение 2 мин реакционную смесь отстаивали и фильтровали через бумажный фильтр, полученный раствор анализировали на ГЖХ «Кристал4000» с детектором пламенной ионизации и программным обеспечением NetChrom [20]. Хроматографическое разделение проводили при следующих условиях: температура инжектора $-188{ }^{\circ} \mathrm{C}$, температура детектора $-230{ }^{\circ} \mathrm{C}$, температура термостата $-188^{\circ} \mathrm{C}$; содержимое колонки: полиэтиленгликольадипинат (20\%) на целите - 545 .

Содержание металлов определяли методом атомно-абсорбционной спектроскопии на спектрометре с электрической атомизацией «КВАНТ-Z.ЭТА-Т» (РФ), с программным обеспечением. Подготовка и проведение атомно-абсорбционных измерений макро- и микроэлементов производили согласно нормативной документации [21].

\section{Обсуждение результатов}

По литературным данным в столонах содержится более 90\% воды [1], в наших исследованиях потеря массы при высушивании составила 80-88\%.

Результаты количественного содержания флавоноидов, углеводов, ПС кумаринов, алкалоидов в исследуемых образцах, собранных из различных популяций, приведены в таблицах 1, 2.

Флавоноидный состав цистанхе солончаковой практически не исследован. При проведении сравнительного анализа водно-спиртовых извлечений нами было установлено, что качественный состав веществ фенольного характера во всех исследуемых образцах практически одинаков. Методом двумерной бумажной хроматографии с использованием различных систем растворителей обнаружено пять веществ фенольной природы. По расположению пятен на хроматограмме вещества предварительно отнесли к би- и тригликозидированным формам флавоноидов. Содержание флавоноидов определили в пределе 2,8-4,8\% в пересчете на а.с.с.

Для роста и развития видов, произрастающих в «жестких условиях», необходимо повышенное содержание углеводов как источников питания. По данным С.К. Кабулова [22], у видов, произрастающих на пустынных территориях Средней Азии при температуре $28-30{ }^{\circ} \mathrm{C}$, отмечено накопление сахарозы, при дальнейшем росте температур воздуха накапливаются моноуглеводы и аминокислоты. В наших исследованиях температура воздуха колебалась в пределах от +19 до $+24{ }^{\circ} \mathrm{C}$ для Алматинской и от +27 до $+35{ }^{\circ} \mathrm{C}-$ Жамбылской областей. 
Таблица 1. Количественное содержание флавоноидов в исследуемых образцах столонов цистанхе солончаковой

\begin{tabular}{|c|c|c|}
\hline \multicolumn{2}{|c|}{ Место сбора, дата заготовки } & \multirow{2}{*}{$\begin{array}{c}\text { Содержание флавоноидов, } \\
\%\end{array}$} \\
\hline область, район & окрестности поселков & \\
\hline Жамб.обл., Сарысуский район & Жайлауколь, 22.04.2013 & 4,8 \\
\hline \multirow[t]{5}{*}{ Алматинская область, Балхашский район } & Кокжиде, 30.04.2014 & 3,1 \\
\hline & Акколь, 30.04.2014 & 3,3 \\
\hline & Береке, 29.04.2014 & 4,6 \\
\hline & Ушжарма, 30.04.2014 & 2,8 \\
\hline & Акжар, 30.04.2014 & 3,8 \\
\hline Алматинская область, Панфиловский район & Айдарлы, 21.04.2015 & 4,2 \\
\hline
\end{tabular}

Таблица 2. Количественное содержание некоторых групп БАВ в столонах цистанхе солончаковой, \% на а.с.с.

\begin{tabular}{|c|c|c|c|}
\hline \multirow[b]{3}{*}{ БАВ } & \multicolumn{3}{|c|}{ Место сбора, дата заготовки } \\
\hline & \multicolumn{2}{|c|}{ Алматинская область } & \multirow{2}{*}{$\begin{array}{c}\text { Жамбылская область, } \\
\text { Сарысуский район, } \\
\text { в песках Мойынкум } \\
22.04 .2013\end{array}$} \\
\hline & $\begin{array}{c}\text { Балхашский район, } \\
\text { в окрестностях п. Акжар, } \\
30.04 .2014\end{array}$ & $\begin{array}{c}\text { Панфиловский район, } \\
\text { в окрестностях п. Айдарлы, } \\
21.04 .2015\end{array}$ & \\
\hline Кумарины & 0,58 & 0,47 & 0,24 \\
\hline Алкалоиды & 0,56 & 0,63 & 0,75 \\
\hline Сапонины & 3,14 & 2,12 & 2,91 \\
\hline Углеводы & 29,5 & 32,12 & 28,9 \\
\hline Полисахариды & 13,7 & 14,7 & 14,1 \\
\hline
\end{tabular}

Результаты количественного анализа свидетельствует о повышенном содержании углеводов (до $32 \%$ от массы а.с.с.) и полисахаридов (до $15 \%$ от массы а.с.с.), что характерно для видов данного рода растений, например у $C$. deserticola более детально изучена структура полисахаридов [23].

Содержание кумаринов и алкалоидов незначительно, хотя по некоторым литературным источникам содержание суммы алкалоидов составляет в C. salsa 0,33\% [13], причем выделены только два алкалоида: бетаин, как наиболее распространенный алкалоид в растительном мире, и метиловый эфир $\mathrm{N}, \mathrm{N}-$ диметилглицина [23].

Имеются сведения по содержанию макро- и микроэлементного состава C. tubulosa, произрастающей на територрии Китая, а также C. Phelypae, произрастающей в Египте [24, 25]. Нами исследован макро- и микроэлементный состав цистанхе солончакой (табл. 3.).

В столонах C. salsa нами обнаружено 10 макро- и микроэлементов, которые в порядке убывания представлены таким образом: $\mathrm{K}>\mathrm{Na}>\mathrm{Mg}>\mathrm{Ca}>\mathrm{Zn}>\mathrm{Al}>\mathrm{Cu}>\mathrm{Mn}>\mathrm{Fe}>\mathrm{Ni}$. Наблюдается высокое содержание натрия, магния и кальция.

Полученные нами результаты по содержанию $\mathrm{K}, \mathrm{Na}, \mathrm{Ca}$ в столонах цистанхе согласуются с имеющимися литературными данными для видов C. tubulosa и C. phelypae [24, 25]. У исследуемого образца $C$. salsa отмечено большее накопление Zn по сравнению с другими обнаруженными микроэлементами, что характерно и для C. phelypae [25], тогда как для китайских образцов характерно накопление $\mathrm{Fe}$ [24].

Таким образом, в исследованных нами столонах цистанхе солончаковой наблюдается накопление К, $\mathrm{Na}$, Са с заметным преобладанием К по сравнению с другими макроэлементами.

Нами проводилось определение амино- и жирных кислот в столонах цистанхе солончаковой, которое позволило выявить 14 аминокислот и восемь жирных кислот (табл. 4, 5).

Из 14 аминокислот, найденных в столонах, максимальными по содержанию являются аргинин, пролин, серин (0,316-0,207\%), а также гистидин, глицин, аланин (0,188-0,178\%). Содержание остальных обнаруженных аминокислот ниже $0,1 \%$ (табл. 4).

Определение содержания жирных кислот паразитирующих видов p. Cistanche Hoffmgg. et Link проводились для C. phelypaea [26], тогда как виды, произрастающие на территории Казахстана, исследуются нами впервые (табл. 5).

В исследуемом сырье обнаружено восемь жирных кислот (табл. 5). Результаты содержания насыщенных жирных кислот - масляной, каприновой, миристиновой составляют менее $0,003 \%$, тогда как стеариновой и капроновой - на порядок выше, 0,04-0,011\%. Из ненасыщенных жирных кислот обнаружены линолевая $0,15 \%$ и олеиновая $0,08 \%$.

Таким образом, выявленные жирные кислоты представлены в основном насыщенными жирными кислотами капроновой и пальмитиновой, а из обнаруженных ненасыщенных - в основном линолевой кислотой. 
Таблица 3. Содержание макро- и микроэлементов в столонах цистанхе солончаковой

\begin{tabular}{l|c|c|c|c|c|c|c|c|c|c}
\hline \multicolumn{1}{c|}{\begin{tabular}{l}
\multicolumn{1}{c}{ Место сбора, } \\
дата заготовки
\end{tabular}} & \multicolumn{8}{c}{ Содержание макро- и микроэлементов C. salsa, мг/кг } \\
\cline { 2 - 10 } & $\mathrm{K}$ & $\mathrm{Na}$ & $\mathrm{Mg}$ & $\mathrm{Ca}$ & $\mathrm{Al}$ & $\mathrm{Fe}$ & $\mathrm{Mn}$ & $\mathrm{Zn}$ & $\mathrm{Cu}$ & $\mathrm{Ni}$ \\
\hline $\begin{array}{l}\text { Алматинская обл., } \\
\text { Панфиловский район, } \\
\begin{array}{l}\text { в окрестностях поселка } \\
\text { Айдарлы, 21.04.2015 }\end{array}\end{array}$ & 62,1 & 24,7 & 12,6 & 0,8 & 15,2 & 3,6 & 4,6 & 70,6 & 6,1 & 0,6 \\
\hline
\end{tabular}

Примечание: содержание Са в \%.

Таблица 4. Содержание аминокислот в цистанхе солончаковой, произрастающей на территории Панфиловского района Алматинской области в окрестностях п. Айдарлы

\begin{tabular}{c|c}
\hline Аминокислота & Массовая доля аминокислот, \% \\
\hline Аргинин & 0,316 \\
Лизин & 0,08 \\
Тирозин & 0,06 \\
Фенилаланин & 0,1 \\
Гистидин & 0,188 \\
Лейцин + Изолейцин & 0,148 \\
Метионин & 0,06 \\
Валин & 0,08 \\
Пролин & 0,207 \\
Треонин & 0,148 \\
Серин & 0,207 \\
Аланин & 0,178 \\
Глицин & 0,188 \\
\hline
\end{tabular}

Таблица 5. Содержание жирных кислот в столонах Cistanche salsa, \% на в.с.с.

\begin{tabular}{l|c|c|c|c|c|c|c|c|c}
\hline \multicolumn{1}{c}{ Место и дата сбора } & \multicolumn{5}{|c}{ Кислота } \\
\cline { 2 - 8 } & $\mathrm{C}_{4: 0}$ & $\mathrm{C}_{6: 0}$ & $\mathrm{C}_{10: 0}$ & $\mathrm{C}_{14: 0}$ & $\mathrm{C}_{16: 0}$ & $\mathrm{C}_{18: 0}$ & $\mathrm{C}_{18: 1}$ & $\mathrm{C}_{18: 2}$ \\
\hline $\begin{array}{l}\text { Саксаульники Панфиловского } \\
\text { района Алматинской области. } \\
30.04 .2013\end{array}$ & 0,006 & 0,012 & 0,005 & 0,003 & 0,12 & 0,04 & 0,08 & 0,15 \\
\hline
\end{tabular}

Примечание. $\mathrm{C}_{4: 0}-$ масляная, $\mathrm{C}_{6: 0}-$ капроновая, $\mathrm{C}_{10: 0}-$ каприновая, $\mathrm{C}_{14: 0}-$ миристиновая, $\mathrm{C}_{16: 0}-$ пальмитиновая, $\mathrm{C}_{18: 0}-$ стеариновая, $\mathrm{C}_{18: 1}-$ олеиновая, $\mathrm{C}_{18: 2}-$ линолевая.

\section{Bblвodbl}

Исследовано качественное и количественное содержание некоторых групп биологически активных веществ в столонах цистанхе солончаковой, собранных в фазу цветения во время экспедиционных выездов в 2013-2015 гг. в пустыни Мойынкум в пределах Сарысуского района Жамбылской области (2013 г.), в саксауловых лесах в окрестностях поселков Береке, Кокжиде, Акколь, Акжар, Ушжарма на территории Балхашского района (2014 г.), в окрестностях поселка Айдарлы Панфиловского района Алматинской области (2015 г.).

Установлено высокое содержание углеводов (до 32\%) и полисахаридов (14\%). Содержание флавоноидов колеблется в пределах 2,8-4,8\%, сапонинов - достигает $3 \%$.

Изучение макро- и микроэлементного состава выявило наибольшее содержание К, $\mathrm{Na}$ и Сa $(0,8 \%)$, среди микроэлементов больше накапливается Zn.

Определен амино- и жирнокислотный состав в столонах цистанхе солончаковой, выявлено 14 аминокислот и восемь жирных кислот. Из выявленных аминокислот преобладают аргинин, пролин и серин.

Анализ жирных кислот преимущественно представлен линолевой, пальмитиновой и капроновой кислотами.

Дальнейшие фитохимические исследования казахстанских видов рода Cistanche Hoffmgg. et Link весьма перспективны для получения современных фитопрепаратов с широким спектром фармакологического действия.

\section{Сиисок литературы}

1. Бейлин И.Г. Паразитизм и эпифитотиология (на примере паразитов из высших растений). М., 1986. 351 с.

2. Байтенов М.С. Флора Казахстана. Родовой комплекс флоры. Т. 2. Алматы, 2001. 280 с. 
3. Павлов Н.В. Флора Казахстана. Т. 8. Алма-Ата, 1965. 448 с.

4. Абдулина С.А. Список сосудистых растений Казахстана. Алматы, 1999. 187 с.

5. Каржаубекова Ж.Ж., Гемеджиева Н.Г. Фитохимическое исследование растений рода цистанхе (Cistanche hoffmgg. et Link) // Вестник КазНУ. Серия биология, 2013. №3/2 (59). С. 388-391.

6. Гемеджиева Н.Г., Ермозанова М.К., Арысбаева Р.Б. Выявление особенностей распространения цистанхе солончаковой в Южном Прибалхашье // Известия НАН РК. Сер. биол. и мед. 2013. №1 (295). С. 10-17.

7. Гемеджиева Н.Г., Ермозанова М.К., Нурханов А. Ресурсный потенциал природных популяций цистанхе в Южном Прибалхашье // Современные тенденции в изучении флоры Казахстана и ее охрана (Байтеновские чтения - 3). Алматы, 2014. С. 239-244.

8. Gemejiyeva N. G., Karzhaubekova Zh. Zh. Life Characteristic of Cistanche Salsa (C.A. Mey.) G. Beck - Perspective Medicinal Plant of the South Peri-Balkhash Lake Saxaul Forests // American Journal of Environmental Protection. Applied Ecology: Problems, Innovations. 2015. Vol. 4. N3-1. Pp. 111- 116.

9. Naran R., Ebringerova A., Hromàdková Z., Patoprstý V. Carbohydrate polymers from underground parts of Cistanche deserticola // Phytochem. 1995. Vol. 40(3). Pp. 709-715.

10. Исабаев С.О., Сарсенбаев К.Н., Барамысова Г.Т., Джиембаев Б.Ж., Кожамжарова Л.С., Колосова Н.Г., Иманбаева А.А. Столоны цистанхе - новый источник биологических веществ. Сообщение $1 / /$ Химический журнал Казахстана. 2010. №1. С. 195-201.

11. Kiboyashi H., Karasawa H., Miyase T. and Fukushima S. Studies on the constituents of Cistanchis Herba II. Isolation and structures of New Iridoids cistanin and cistachlorine // Chem. Pharm. Bull. 1984. N32. Pp. 1729-1734.

12. Капсалямова Э.Н. Разработка состава и технологии лекарственной формы на основе полифенольных соединений Cistanche salsa (C.A. Mey.) G. Beck: автореф. дис. ...канд. фарм. наук. Алматы, 2010. 24 с.

13. Юнусов С.Ю. Алкалоиды. Ташкент, 1974. 320 с.

14. Shimoda H., Tanaka J., Takahara Y., Takemoto K., Shan S.-J., Su M.-H. The hypocholesterolemic effects of Cistanche tubulosa extract, achinese traditional crude medicine, in mice // American Journal of Chinese Medicine. 2009. Vol. 37. Pp. 1125-1138.

15. Zhang C.Z., Wang S.X., Zhang Y., Chen J.P., Liang X.M. In vitro estrogenic activities of Chinese medicinal plants traditionally used for the management of menopausal symptoms // J. Ethnopharmacology. 2005. Vol. 98. Pp. 295-300.

16. Maruyama S., Hashizume S., Tanji T., Yamada K., Tachibana H. Cistanche salsa extract enhanced antibody production in human lymphnodelymphocytes // Pharmacology. 2008. Vol. 2. Pp. 341-348.

17. Казбекова А.Т., Мухамбетов Д.Д., Сейтембетов Т.С., Тулеуов Б.И., Мусабекова А.С. Исследование антиоксидантного и антибактериального свойства экстракта цистанхе солончаковой // Астана медициналық журналы. 2011. №4 (66). С. 115-118.

18. Музычкина Р.А., Корулькин Д.Ю. Методология исследования растительных метаболитов. Алматы, 2012. $324 \mathrm{c}$.

19. Комарова Н.В., Каменцев Я.С. Практическое руководство по использованию систем капиллярного электрофореза. СПб., 2006. 212 с.

20. ГОСТ Р 51483-99. Масла растительные и жиры животные. Определение методом газовой хроматографии массовой доли метиловых эфиров индивидуальных жирных кислот к их сумме. М., 2005. 8 с.

21. ГОСТ 30178-96. Сырье и продукты пищевые. Атомно-абсорбционный метод определения токсичных элементов. М., 2003. 32 с.

22. Кабулов С.К. Приспособление растений к дефициту влаги. Ташкент, 1981. 95 с.

23. Yong J., Peng-Fei T. Analysis of chemical constituents in Cistanche species // J. Chromatography A, 2009. Vol. 1216. Pp. 1970-1979.

24. Du Y., Sheng J.-H., Cui X.-S., Zhai Z.-X., Dong H.-H., Guo Y.-H. Determination of the content of mineral elements in Cistanche tubulosa from different area// Spectroscopy \& Spectral Analysis. 2012. Vol. 32. N10. Pp. 2824-2827.

25. Elwakil H.E., Abdelsalam N.R., Abd El-Azeem R.M., Hemeida A.A. Abass N.Y., Nasar A. Morphological and molecular genetics characterization of holoparasitic plant; Cistanche phelypeae L. in Siwa Oasis, Egypt. URL: http://www.academia.edu/6034293/

26. Ramadan M.F., Hernawy H.T.M., Gomoa A.M. Bioactive lipids and fatty acids profile of Cistanche phelypaea // J. Verbrauch. Lebensm. 2011. Vol. 6. Pp. 333-338.

Поступило в редакияию 14 июня 2016 г. 
Karzhaubekova Zh.Zh. ${ }^{1}$, Gemedjiyeva N.G. ${ }^{l}$, Nabiyeva Zh.S. ${ }^{2}$ TO THE PHYTOCHEMICAL INVESTIGATION OF CISTANCHE SALSA (OROBANCHACEAE)

${ }^{I} R S E$ «Institute of botany and phytointroduction» CS MES RK, ul. Timiryazeva, 36d, Almaty, 050040 (Republic of Kazakhstan)e-mail: zhanna1322@mail.ru

${ }^{2}$ Almaty technology university, ul. Tole bi, 100, Almaty, 050012 (Republic of Kazakhstan)

This paper shows the results of content of few biological active compounds such as flavonoids, coumarines, alkaloids, and polisaccharides in stolones of Cistanche salsa which grows in saxaul forest of Peri-Balkhash and Panfilov administrative areas on Almaty region and in the sands of Moyynkum on the territory of Zhambyl region.

For the first time the content of fatty and amino acids also macro - and microelements were studied from stolones of Cistanche which have been collected from the Panfilov district. There is found 14 amino- and 8 fatty acids. From the identified amino acids prevailing arginine, proline and serine. The analysis of fatty acids presented predominantly by linoleic and palmitic acids $(>0,1 \%)$. Macro- and microelement composition revealed the presence of 10 elements such as $\mathrm{K}, \mathrm{Na}, \mathrm{Mg}, \mathrm{Ca}$, $\mathrm{Al}, \mathrm{Fe}, \mathrm{Mn}, \mathrm{Zn}, \mathrm{Cu}$ and $\mathrm{Ni}$. And the highest concentration observed for $\mathrm{K}, \mathrm{Na}$ and $\mathrm{Ca}(0,8 \%)$, among the trace elements $\mathrm{Zn}$ accumulates more.

A comparative analysis of water-alcohol extracts showed the qualitative composition of the phenolic compounds of studied samples is practically identical. By two-dimensional paper chromatography and uses of variety of solvent systems allowed to found 5 phenolic substances. The quantitative content of flavonoids defined within $2,8-4,8 \%$.

There was defined the high content of carbohydrates (up to $32 \%$ ) and polysaccharides ( $>13 \%$ ).

Keywords: Cistanche salsa, phytochemical analysis, amino- and fatty acids content, macro- and microelements.

\section{References}

1. Beilin I.G. Parazitizm i epifitotiologiia (na primere parazitov iz vysshikh rastenii). [Parasitism and epifitotiologiya (for example, parasites of higher plants)]. Moscow, 1986, 351 p. (in Russ.).

2. Baitenov M.S. Flora Kazakhstana. Rodovoi kompleks flory. [Flora of Kazakhstan. Generic complex flora]. Almaty, 2001, vol. 2, 280 p. (in Russ.).

3. Pavlov N.V. Flora Kazakhstana. [Flora of Kazakhstan]. Alma-Ata, 1965, vol. 8, 448 p. (in Russ.).

4. Abdulina S.A. Spisok sosudistykh rastenii Kazakhstana. [List of vascular plants in Kazakhstan]. Almaty, 1999,187 p. (in Russ.).

5. Karzhaubekova Zh.Zh., Gemedzhieva N.G. Vestnik KazNU. Seriia biologiia, 2013, no. 3/2 (59), pp. 388-391. (in Russ.).

6. Gemedzhieva N.G., Ermozanova M.K., Arysbaeva R.B. Izvestiia NAN RK. Cer. biol. i med. 2013, no. 1 (295), pp. 10-17. (in Russ.).

7. Gemedzhieva N.G., Ermozanova M.K., Nurkhanov A. Sovremennye tendentsii v izuchenii flory Kazakhstana $i$ ee okhrana (Baitenovskie chteniia - 3). [Current trends in the study of the flora of Kazakhstan and its protection (Baytenovskie reading - 3)]. Almaty, 2014, pp. 239-244. (in Russ.).

8. Gemejiyeva N. G., Karzhaubekova Zh. Zh. American Journal of Environmental Protection. Applied Ecology: Problems, Innovations, 2015, vol. 4, no. 3-1, pp. 111-116.

9. Naran R., Ebringerova A., Hromàdková Z., Patoprstý V. Phytochem., 1995, vol. 40(3), pp. 709-715.

10. Isabaev S.O., Sarsenbaev K.N., Baramysova G.T., Dzhiembaev B.Zh., Kozhamzharova L.S., Kolosova N.G., Imanbaeva A.A. Khimicheskii zhurnal Kazakhstana, 2010, no. 1, pp. 195-201. (in Russ.).

11. Kiboyashi H., Karasawa H., Miyase T., Fukushima S. Chem. Pharm. Bull., 1984, no. 32, pp. 1729-1734.

12. Kapsaliamova E.N. Razrabotka sostava i tekhnologii lekarstvennoi formy na osnove polifenol'nykh soedi-nenii Cistanche salsa (C.A. Mey.) G. Beck: avtoref. dis. ...kand. farm. nauk. [Development of composition and formulation technology based on polyphenol compounds Cistanche salsa (C.A. Mey.) G. Beck: Author. Dis. ... Cand. Pharm. sciences]. Almaty, 2010, 24 p. (in Russ.).

13. Iunusov S.Iu. Alkaloidy. [Alkaloids]. Tashkent, 1974, 320 p. (in Russ.).

14. Shimoda H., Tanaka J., Takahara Y., Takemoto K., Shan S.-J., Su M.-H. American Journal of Chinese Medicine, 2009, vol. 37, pp. 1125-1138.

15. Zhang C.Z., Wang S.X., Zhang Y., Chen J.P., Liang X.M. J. Ethnopharmacology, 2005, vol. 98, pp. 295-300.

16. Maruyama S., Hashizume S., Tanji T., Yamada K., Tachibana H. Pharmacology, 2008, vol. 2, pp. 341-348.

17. Kazbekova A.T., Mukhambetov D.D., Seitembetov T.S., Tuleuov B.I., Musabekova A.S. Astana meditsinalyқ zhurnaly. 2011, no. 4 (66), pp. 115-118. (in Russ.).

18. Muzychkina R.A., Korul'kin D.Iu. Metodologiia issledovaniia rastitel'nykh metabolitov. [The methodology of the study of plant metabolites]. Almaty, 2012, 324 p. (in Russ.).

19. Komarova N.V., Kamentsev Ia.S. Prakticheskoe rukovodstvo po ispol'zovaniiu sistem kapilliarnogo elektroforeza. [Practical guidance on the use of capillary electrophoresis systems]. St. Petersburg, 2006, 212 p. (in Russ.).

20. GOST R 51483-99. Masla rastitel'nye i zhiry zhivotnye. Opredelenie metodom gazovoi khromatografii massovoi doli metilovykh efirov individual'nykh zhirnykh kislot $k$ ikh summe. [GOST 51483-99. Vegetable oils and animal fats. Determination by gas chromatography of methyl esters of mass fraction of individual fatty acids to their sum]. Moscow, 2005, 8 p. (in Russ.).

\footnotetext{
* Corresponding author.
} 
21. GOST 30178-96. Syr'e i produkty pishchevye. Atomno-absorbtsionnyi metod opredeleniia toksichnykh elementov. [GOST 30178-96. Raw materials and food products. Atomic absorption method for determination of toxic elements]. Moscow, 2003, 32 p. (in Russ.).

22. Kabulov S.K. Prisposoblenie rastenii $k$ defitsitu vlagi. [The adaptation of plants to water deficit] Tashkent, 1981, 95 p. (in Russ.).

23. Yong J., Peng-Fei T. J. Chromatography A, 2009, vol. 1216, pp. 1970-1979.

24. Du Y., Sheng J.-H., Cui X.-S., Zhai Z.-X., Dong H.-H., Guo Y.-H. Spectroscopy \& Spectral Analysis, 2012, vol. 32, no. 10, pp. 2824-2827.

25. Elwakil H.E., Abdelsalam N.R., Abd El-Azeem R.M., Hemeida A.A. Abass N.Y., Nasar A. Morphological and molecular genetics characterization of holoparasitic plant; Cistanche phelypeae L. in Siwa Oasis, Egypt, URL: http://www.academia.edu/6034293/

26. Ramadan M.F., Hernawy H.T.M., Gomoa A.M. J. Verbrauch. Lebensm., 2011, vol. 6, pp. 333-338.

Received June 14, 2016

Revised September 28, 2016 